\title{
PRS KOREA 2016: 50th Anniversary of the Korean Society of Plastic and Reconstructive Surgeons and Another Successful Congress for Plastic and Reconstructive Surgery
}

\author{
Dae Hyun Lew
}

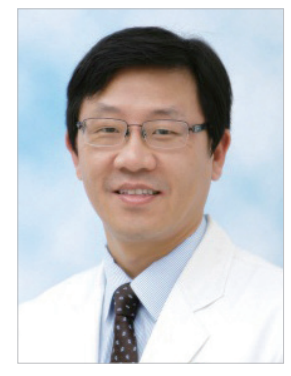

Chairman of the Korean Society of Plastic and Reconstructive Surgeons

Department of Plastic and Reconstructive Surgery, Institute for Human Tissue Restoration, Severance Hospital, Yonsei University College of Medicine, Seoul, Korea

The Korean Society of Plastic and Reconstructive Surgeons (KSPRS) celebrated its 50th anniversary in 2016, and has established itself as a distinguished academic society for plastic surgery. In the 1950s, when the Korean War had a devastating impact on South Korea (hereafter, Korea), doctors pioneered the field of plastic surgery in Korea and treated injured patients with war wounds and children with congenital disorders. Following the initial introduction of plastic surgery into Korea, the KSPRS was founded to establish plastic surgery as an academic field in medicine and has trained plastic surgery specialists ever since. Thanks to the efforts and accomplishments of KSPRS members since its inception, the field of plastic surgery in Korea has gained international recognition beyond Asia, and is currently spreading its academic achievements and surgical technologies as part of the broader phenomenon of the Korean Wave.

No plastic surgery techniques were available in Korea in 1945, when Korea gained independence from Japan. However, medicine in Korea took a new turn with the entry of Western doctors and the introduction of Western medical literature into Korea after independence. Some surgeons among the missionary doctors performed skin grafts on patients with facial and finger disfigurement and contracture due to severe and chronic ulcers, defects, and burns on the skin. With the outbreak of the Korean War in 1950, medical personnel from the US and the United Nations began the active treatment of patients with war wounds. Among them, Dr. Millard, a US military doctor, and Dr. Stenstrom, a doctor at the Swedish Red Cross Field Hospital in
Busan, performed various plastic surgery procedures, including treatment for cleft lip and palate patients and reconstructive procedures. Despite the presence of these talented foreign doctors in Korea, they remained concentrated on their duties of treating injured patients and were not able to assist in the general development of medicine, especially plastic surgery, in Korea. In August 1961, Dr. Jae-duk Lew, who had specialized in plastic surgery at Allentown General Hospital in Pennsylvania, US, founded the Plastic Surgery Department at Yonsei University Severance Hospital, thereby establishing plastic surgery as a specialized field of medicine and training specialists in the field for the first time in Korea [1].

Over the years, plastic surgery eventually became acknowledged as a specialized field of medicine, and on May 15, 1966, the KSPRS held its inaugural general meeting. With the founding of the KSPRS, its members focused their efforts on education regarding the general concepts of plastic surgery and engaged in academic discussions, in order to increase interest and awareness among the general public and physicians. The KSPRS continued its efforts and made great scholarly achievements, and in 1970, the KSPRS was accepted as an official member of the International Confederation for Plastic Reconstructive and Aesthetic Surgery (IPRAS) [1]. The KSPRS held its first conference on November 8, 1968. It has continued this tradition ever since, and gathered in the fall of 2016 for its 74th conference.

PRS KOREA 2016 was organized in commemoration of the 
50th anniversary of the KSPRS, and it was successfully held from November 17 to 20 in Seoul, receiving rave reviews. Over the 4 days of the conference, a total of 1,516 attendees participated, Egypt and China served as guest nations, and 42 international invited speakers from 12 nations and 301 international attendees from 29 nations participated, indicating that it had become an internationally renowned conference. The KSPRS selected English as the official language for the conference and provided the attendees with interpreters to assist them with simultaneous interpretation services throughout the conference. Currently, since there is no prominent international meeting of plastic and reconstructive surgeons in the Asia-Pacific region, it is expected that PRS Korea will be able to serve as the foremost international conference on plastic surgery in the region.

The official journal of the KSPRS is Archives of Plastic Surgery (Arch Plast Surg, APS) which continues Journal of the Korean Society of Plastic and Reconstructive Surgeons, which was launched in 1974. APS is a peer-reviewed open-access journal that publishes articles in all fields of plastic and reconstructive surgery, and aims to be the leading forum for communications regarding techniques related to Asian patients' needs. APS also embraces its identity as the leading plastic surgery journal in Asia, aiming to be the main forum for communication among plastic surgery scholars and clinicians in the Asia-Pacific region and beyond, and the main vehicle for presenting this group's technical innovations to an international audience [2]. APS is indexed, tracked, and covered by E-SCI, PubMed, PubMed Central
(PMC), KoreaMed, Synapse, KoMCI, SCOPUS, Embase, CAS, CrossRef, and Google Scholar.

The KSPRS will continue its active engagement and efforts to thrive as a leading international academic community in the field of plastic surgery. Since APS succeeded in becoming indexed in E-SCI in 2016, we hope to make further efforts to become a highly esteemed journal that provides a space for international plastic surgery specialists to submit their research and to exchange scholarly ideas, and eventually to be indexed in SCI.

\section{REFERENCES}

1. Institute of History of Medicine Yonsei University. Jae-duk Lew: a pioneer of plastic surgery in Korea. Yonsei J Med Hist 2010;13:143-69.

2. Korean Society of Plastic and Reconstructive Surgeons. Archives of Plastic Surgery: aims and scope [Internet]. Seoul: The Society; [cited 2017 Jan 9]. Available from: http://e-aps.org/index.php?body=aims.

Correspondence: Dae Hyun Lew

Department of Plastic and Reconstructive Surgery, Institute for Human Tissue Restoration, Severance Hospital, Yonsei University College of Medicine, 50-1 Yonsei-ro, Seodaemoon-gu, Seoul 03722, Korea Tel: +82-2-2228-2217, Fax: +82-2-393-6947, E-mail: dhlew@yuhs.ac

No potential conflict of interest relevant to this article was reported.

Received: 11 Jan 2017 • Revised: 11 Jan 2017 • Accepted: 11 Jan 2017 pISSN: 2234-6163 • elSSN: 2234-6171

https://doi.org/10.5999/aps.2017.44.1.1 • Arch Plast Surg 2017;44:1-2 